\title{
A study of micronutrient status in multidrug resistant tuberculosis patients at a tertiary care center
}

\author{
M. Jahnavi ${ }^{1}$, GP Vignan Kumar,", Rajesh Reddy ${ }^{3}$, Subhash B. Reddy ${ }^{4}$, B. Raviteja ${ }^{5}$ \\ ${ }^{1}$ Undergraduate, ${ }^{2}$ Professor \& HOD, ${ }^{3}$ Assistant Professor, ${ }^{4,5}$ Postgraduate, ${ }^{2-5}$ Dept. of Respiratory Medicine, Narayana Medical \\ College \& Hospital, Nellore, Andhra Pradesh, India
}

*Corresponding Author:

Email: research.nmch1@rediffmail.com

\begin{abstract}
Introduction: Micronutrients deficiency is supposed to impair the overall immune function and causes increased resistance to infection. Such a relationship exists even in tuberculosis. A major threat is multidrug resistant tuberculosis (MDR-TB). In India, few studies are available to discuss about risk factors and serum zinc and selenium status in MDR-TB.

Material and Methods: A case control study of 25 diagnosed MDR-TB patients from Damian foundation and 25 healthy controls from Narayan Medical College were recruited after laboratory tests, chest X-ray and clinical history. $5 \mathrm{ml}$ of blood collected and serum zinc and selenium levels were assessed for both groups and correlated with demographic factors, duration of treatment, and BMI.

Results: The results indicate that the MDR-TB patients have altered profile of the serum zinc and serum selenium in their sera and this could be more due to the active disease, causing oxidative stress which depletes the micronutrients. In this study, the mean serum zinc levels were $79.08 \pm 14.2 \mu \mathrm{g} / \mathrm{dL}$ and $91.1 \pm 15.2 \mu \mathrm{g} / \mathrm{dL}$ in case and control groups respectively. Serum selenium levels were $56.2 \pm 11.1 \mu \mathrm{g} / \mathrm{dL}$ and $65.2 \pm 4.2 \mu \mathrm{g} / \mathrm{dL}$ in case and control groups respectively. In both the groups micronutrient levels showed statistical significant.

Conclusions: The risk factors in our study, such as lower level of serum zinc was one of the concern for the development of MDR-TB and an attempt to minimize them might contribute to control the upward slope of MDR-TB.
\end{abstract}

Keywords: Immune status; Serum zinc; Serum selenium; TB.

\section{Introduction:}

Globally, tuberculosis (TB) is a major public health challenge and now ranks alongside HIV as a leading cause of death worldwide. In recent years, progress in TB control and eradication has been major problem by the emergence of drug resistant strains of Mycobacterium tuberculosis (Mtb). India is estimated to have a MDR-TB rate of $2.9 \%$ and $14.3 \%$ among new and relapse cases and it was ranked highest burden in Asia. The innate immune cells; macrophages, neutrophils and dendritic cells, acts as first responder, activator of adaptive immunity and effector cell in Mtb infection. Mtb bacilli upon entry into the lungs are engulfed by resident macrophages and dendritic cells. This leads to transformation of macrophages from a resting state to an activated state with characteristic feature of increased oxygen uptake, enlargement and increased protein synthesis. Also there is an increased influx of neutrophils to the lungs in human TB. Macrophage and neutrophil apoptosis have also been reported to be a potent mechanism for control of inflammation and removal of infected cells in Mtb infection. These lead to a high rate of cellular turn over during infection and increased demand for essential nutrients by the immune cells. Malnutrition is associated with tuberculosis and plays the role in the development of the disease [1,2]. In Tanzania, study reported that malnutrition was evident before and after TB treatment [3].
In India, limited information is available on the zinc status in MDR-TB cases. Zinc plays a vital role in immunity. Macrophages are also affected by zinc deficiency. In person with Zinc deficiency, there was an increased susceptibility to variety of pathogens including $\mathrm{M}$. tuberculosis. The development of $\mathrm{T}$ and $\mathrm{B}$ cells are also affected by zinc deficiency.

Micronutrient deficiency has been described in pulmonary TB patients and several studies have suggested that the patients with TB are at high risk of deficiency of zinc and selenium. Micronutrient deficiency has been reported to impair resistance to infection, lead to active TB disease and poor outcome of anti-TB chemotherapy, this present study therefore determined the serum level of micronutrients $[\mathrm{Zn}, \mathrm{Se}]$ in MDR-TB patients at the anti-TB chemotherapy.

\section{Material and Methods:}

A case control study carried out at Narayana Medical College in collaboration with Damian foundation, Nellore, Andhra Pradesh to determine the $\mathrm{Zn}$, Se and other risk factors associated with MDR-TB. Study participants: Twenty-five patients admitted into the MDR-TB center, Damien Foundation, Nellore, Andhra Pradesh, India for anti-TB treatment were recruited for the study after obtaining written informed consent.

Inclusion and exclusion criteria: Only the pulmonary MDR-TB patients from Nellore district registered at Damien Foundation, Nellore were included in the study 
as cases. Patients who were unwilling to participate in the study, extra-pulmonary tuberculosis and patients not turning up at the hospital during the study period were excluded.

Patients were previously diagnosed as being infected with Isoniazid and Rifampicin resistant strains of Mtb using clinical history, chest X-ray and line probe assay test. Twenty five age matched healthy participants were kept as controls. Five milliliters of blood was drawn from the anti cubital fossa vein into heparin tubes before the commencement of chemotherapy, and blood samples were centrifuged and plasma obtained was analyzed. The plasma was collected and refrigerated till analysis. In both the groups the micronutrient [serum zinc, serum selenium] levels were measured using Atomic Absorption Spectrophotometer [SHIMDAZU, Japan] and a comparative analysis of the findings was made.

MDR-TB treatment protocol: All bacteriologically confirmed MDR-TB patients received an intensive phase for 6-8 months in the hospital followed by 12 months of continuation phase in the community based on the updated RNTCP guidelines. Standardized treatment regimen was used including five drugs: Kanamycin/Amikacin, Levofloxacin, Prothionamide, Cycloserine, Pyrazinamide (with Pyridoxine). This present study was conducted during the intensive phase of treatment.

\section{Micronutrient analysis:}

Serum levels of micronutrient (Zinc and Selenium) were determined by Atomic Absorption
Spectrophotometer [SHIMDAZU, Japan] and a comparative analysis of the findings were made.

\section{Statistical analysis:}

Data obtained were analyzed by statistical package for social sciences (SPSS) version 17.0. Independent Student $t$-test was used to compare the mean values of MDR TB patients and controls while paired $t$-test was used to compare the mean values of MDR TB patients before the commencement of chemotherapy. Values were considered significant at $p<0.05$. The two groups were compared based on various demographic factors, duration of treatment, body mass index.

\section{Results:}

Out of 25 MDR-TB cases, highest percentage of MDRTB (40\%) were found within the age group 21-30 years, followed by age group 41-50 years (35\%) and $31-40$ years with $25 \%$. Among 25 MDR-TB patients, $15(60 \%)$ were male and $10(40 \%)$ were female. 25 controls (14 male and 11 female) with a mean age of 35 and age ranging from 22 to 56 years were included.

A total of 15 of MDR-TB cases had a history of drug default and 10 had history of irregular treatment of antitubercular therapy.

The mean $\pm \mathrm{SD}$ of serum zinc levels were found to be $79.08 \pm 14.2 \mu \mathrm{g} / \mathrm{dL}$ and $91.1 \pm 15.2 \mu \mathrm{g} / \mathrm{dL}$ in cases and control groups respectively.

The mean $( \pm \mathrm{SD})$ serum selenium levels in cases and control groups were found to be $56.2 \pm 11.1 \mu \mathrm{g} / \mathrm{dL}$ and $65.2 \pm 4.2 \mu \mathrm{g} / \mathrm{dL}$.

Table 1: Analysis of serum zinc and selenium levels in MDR-TB and controls and their significant association

\begin{tabular}{|c|c|c|c|c|}
\hline \multicolumn{5}{|c|}{ Zinc $(80-120 \mu \mathrm{g} / \mathrm{L})$} \\
\hline BMI & Normal & Undernourished & Total & $p$ value \\
\hline Normal & $6(54.55)$ & $5(38.46)$ & $11(45.83)$ & \multirow{3}{*}{$p>0.05$} \\
\hline Low & $5(45.45)$ & $8(61.54)$ & $13(54.17)$ & \\
\hline Total & $11(100)$ & $13(100)$ & $24(100)$ & \\
\hline \multicolumn{5}{|c|}{ Selenium $(55-65 \mu \mathrm{g} / \mathrm{L})$} \\
\hline Normal & $7(53.84)$ & $4(46.16)$ & $11(45.83)$ & \multirow{3}{*}{$p>0.05$} \\
\hline Low & $6(46.15)$ & $7(53.85)$ & $13(54.17)$ & \\
\hline $\begin{array}{l}\text { Grand } \\
\text { Total }\end{array}$ & $13(100)$ & $11(100)$ & $24(100)$ & \\
\hline \multicolumn{2}{|c|}{$\begin{array}{l}\text { Micronutrients } \\
\text { level }\end{array}$} & MDR-TB & Controls & $p$ value \\
\hline \multicolumn{2}{|c|}{ Zinc $(80-120 \mu \mathrm{g} / \mathrm{L})$} & $79.29 \pm 10.19$ & $91.1 \pm 15.2$ & 0.01 \\
\hline \multicolumn{2}{|c|}{$\begin{array}{l}\text { Selenium(55-65 } \\
\mu \mathrm{g} / \mathrm{L})\end{array}$} & $55.71 \pm 6.09$ & $65.2 \pm 4.2$ & 0.01 \\
\hline
\end{tabular}

\section{Discussion:}

Mostly, MDR-TB will develop due to interruption in the course of antibiotics and the insufficiency of the drug to kill $100 \%$ of bacteria. WHO estimated that 45,000 people fell ill with MDR-TB in 2012 (WHO, 2013) [4]. Low- and middle-income countries accounted for 95\% of TB deaths (WHO, 2013a) [5]. More people are dying of the disease with the emergence and proliferation of MDR-TB bacteria (MDR-TB; WHO, 2013a) [6]. Malnutrition is a risk factor for the development of pulmonary $\mathrm{TB}$ and is responsible for the premature death due to active 
disease. In India, studies are limited on the nutritional status in MDRTB patients. Current study aimed to analyse the zinc and selenium nutritional status of MDR-TB patients.

Malnutrition may predispose the individuals in the latent infection to active disease because malnutrition affects the cell-mediated immunity [7]. We analysed serum zinc levels in MDR-TB patients, as we assumed that zinc deficiency may play an important role for developing MDR-TB.

In our study we observed $13 / 24(54.17 \%)$ of our patients had hypozincaemia, among them 8/13 $(61.54 \%)$ were undernourished. A study reports says that hypozincaemia is often observed at the time of diagnosis and this difference was statistically significant $(\mathrm{P}<0.05)$ [8]. In a study also lower level of serum zinc was observed in MDR-TB than controls [9].

Lower level of serum zinc was reported in some studies in the same condition $[10,11]$. Serum zinc level in pulmonary TB was $65.53(9.8) \mu \mathrm{g} / \mathrm{dl}$ and 52.5 (19.5) $\mu \mathrm{g} / \mathrm{dl}$ in Ramakrishnan et al., and Ahmad et al., studies respectively and these levels were lower than normal ranges.

Selenium deficient lymphocytes were less able to proliferate in response to mitogen [12]. Current study analysis showed that the mean selenium level is $55.71 \pm$ $6.09 \mu \mathrm{g} / \mathrm{L}$ in the Mtb group and $65.2 \pm 4.2 \mu \mathrm{g} / \mathrm{L}$ in the control group.

Selenium is also important for achieving optimal functionality of neutrophils. In a study from Malawi involving $801 \mathrm{~TB}$ patients of whom 579 were HIVpositive, selenium deficiency was found in $87 \%$ of the participants when cut-off for deficiency was set at 0.89 $\mu \mathrm{mol} / \mathrm{L}(3)$ [13].

Patients $(98 \%)$ in our study had previous history of TB. Various studies had shown very significant correlation between past history of TB and MDR-TB [14-17]. Also, drugs that are of poor quality or less in quantity, especially in developing countries contribute to MDR-TB [18]. According to a study, $67 \%$ of cases missed medicine at least a few weeks during their previous treatment [19]. Irregularity in taking medicine was shown statistically associated with MDR-TB which was correlated with previous studies [20-22].

In this study, younger age (21-30 years) was found to be statistically associated with MDR-TB. The highest number of MDR-TB patients of the productive age group might be due to the exposure of these age group people to different environment during their work and activities that would make their health more prone to infection by TB organisms [23,24].

\section{Conclusion:}

Now a days, MDR-TB is a big challenge to control in the world. Identifying region specific risk factors of MDR-TB infection which are reflective of nutritional status may help to prevent the proliferation of the disease. We recommended further study to compare serum zinc and selenium level of MDR-TB with pulmonary tuberculosis in a large sample size.

\section{Conflict of interest: None}

\section{References:}

1. Gupta KB, Gupta R, Atreja A, Verma M, Vishvkarma S. Tuberculosis and nutrition. Lung Ind 2009;26(1):9-16.

2. Kennedy N, Ramsay A, Uiso L, Gutmann J, Ngowi FI, Gillespie SH. Nutritional status and weight gain in patients with pulmonary tuberculosis in Tanzania. Trans R Soc Trop Med Hyg 1996;90:162-6.

3. Zachariah R, Spielmann MP, Harries AD, Salaniponi FM. Moderate to severe malnutrition in patients with tuberculosis is a risk factor associated with early death. Trans R Soc Trop Med Hyg 2002;96(3):291-4.

4. WHO (2013). Global Tuberculosis report, World Health Organization, Geneva. Available from URL: http://apps.who.int/iris/bitstream/10665/91355/1/9789241 564656_eng.pdf?ua=1. Last accessed 2018 on August 11.

5. World Health Organization. (WHO, 2013a). Global Tuberculosis Report 2013. Available from URL: http://apps.who.int/iris/bitstream/10665/91355/1/9789241 564656_eng.pdf?ua=1. Last accessed 2018 on August 11.

6. World Health Organization. (WHO, 2013a).Global Tuberculosis Report 2013. Retrieve from: http://apps.who.int/iris/bitstream/10665/91355/1/9789241 564656_eng.pdf?ua $=1$

7. Cegielski JP, McMurray DN. The relationship between malnutrition and tuberculosis: evidence from studies in humans and experimental animals. Int J Tuberc Lung Dis 2004;8(3):286-98

8. Koyanagi A, Kuffo D, Gresely L, Shenkin A, Cuevas LE. Relationships between serum concentrations of Creactive protein and micronutrients, in patients with tuberculosis. Ann Trop Med Parasitol 2004;98(4):391-9.

9. Barman N, Ghosh D, Rahman MQ, Uddin MN, Ahmed S, Paul D, Sultana T, Ahmed AN, Haque MA. Assessment of risk factors of multidrug resistant tuberculosis with emphasis on serum zinc. Bangladesh Med J 2014;43(1):3-8

10. Ahmad I, Srivastava VK, Prasad R, Yusuf M, Saleem M, Ali W. Deficiency of Micronutrient Status in Pulmonary Tuberculosis Patients in North India. Biomed Res 2011;22(4):449-54.

11. Ramakrishnan K, Shenbagarathai R, Kavitha K, Uma A, Balasubramaniam R, Thirumalaikolundusubramanian $\mathrm{P}$. Serum zinc and albumin levels in pulmonary tuberculosis patients with and without HIV. J Infect Dis 2008;61:2024.

12. Arthur JR, McKenzie RC, Beckett GJ. Selenium in the immune system. J Nutr 2003;133(5):1457S-9S.

13. van Lettow M, Harries AD, Kumwenda JJ, Zijlstra EE, Clark TD, Taha TE, et al. Micronutrient malnutrition and wasting in adults with pulmonary tuberculosis with and without HIV co-infection in Malawi. BMC Infect Dis 2004;4(1):61.

14. Marahatta SB, Kaewkungwal J, Ramasoota P, Singhasivanon P. Risk factors of Multidrug Resistant Tuberculosis in central Nepal: A pilot study. Kathmandu Univ Med J 2010;8(32):392-95.

15. Federal Ministry of Health of Ethiopia. Guidelines for clinical and programmatic management of TB, leprosy and TB/HIV in Ethiopia 2012.

16. Hirpa S, Medhin G, Girma B, Melese M, Mekonen A, Suarez P, Ameni G. Determinants of multidrug-resistant tuberculosis in patients who underwent first-line 
treatment in Addis Ababa: a case control study. BMC Public Health 2013;13(1):782.

17. Biadglegne F, Sack U, Rodloff AC. Multidrug-resistant tuberculosis in Ethiopia: efforts to expand diagnostic services, treatment and care. Antimicrob Resist Infect Control 2014;3(1):31.

18. Sharma SK, Mohan A. Multidrug-resistant tuberculosis. Ind J Med Res 2004;120:354-76.

19. Pant R, Joshi M, Pandey KR, Sharma S, Pandey T and Pandey S. Risk factors assessment of multidrug-resistant tuberculosis. J Nepal Health Res Counc 2009;7(15):8992.

20. Barroso EC, Mota RM, Santos RO, Sousa AL, Barroso JB, Rodrigues JL. Risk factors for acquired multidrugresistant tuberculosis. J de Pneumologia 2003;29(2):8997.

21. Kritski AL. Risk factors for multidrug-resistant tuberculosis. J de Pneumologia 2003;29(2):55-6.

22. Amin MN, Rahman MA, Flora MS and Azad MAK. Factors associated with multidrug-resistant tuberculosis. Ibrahim Med Coll J 2009;3(1):29-33.

23. Vander-Werf MJ, Langendam MW, Huitric E and Manissero D. Multidrug-resistance after inappropriate tuberculosis treatment: a meta analysis. Eur Respir J 2012;39(6):1511-519.

24. Lange C, Abubakar I, Alffenaar JW, Bothamley G, Caminero JA, Carvalho AC, et al. Management of patients with multidrug-resistant/extensively drugresistant tuberculosis in Europe: a TBNET consensus statement. Eur Respir J 2014;44(1):23-63.

How to cite this article: Jahnavi M., Kumar GP V., Reddy R, Reddy S. B., Raviteja B. A study of micronutrient status in multidrug resistant tuberculosis patients at a tertiary care center. $I P$ Indian $J$ Immunol Respiratory Med 2018;3(3):94-97. 